\title{
Seasonal Variation in Leaf Component Allocation in Normal, Afila, and Afila-tendrilled Acacia Pea Foliage Near-isolines
}

\author{
I.L. Goldman ${ }^{1}$ \\ Department of Horticulture, University of Wisconsin, Madison, WI 53706-1597 \\ E.T. Gritton \\ Department of Agronomy, University of Wisconsin, Madison, WI 53706-1597
}

Additional index words. Pisum sativum, foliage type

\begin{abstract}
In pea (Pisum sativum L.) the af gene replaces leaflets with tendrils, and the tac gene restores small leaflets to the terminal portion of the tendrils of afaf plants. Normal (AfAf-TacTac), afila (afaf-TacTac), and afila-tendrilled acacia (afaf-tactac) near-isogenic lines in three genetic backgrounds were evaluated for 2 years in two locations to determine allocation of foliage area and weight of foliage components throughout the growing season. The percentage of total leaf area and weight due to stipule, tendril, leaflet, and tac leaflet were measured three times during the growing season in each environment. Highly significant foliage-type effects were detected for the percentage of leaf area and weight due to stipule and tendril at each sampling date. The pea leaf canopy exhibits large fluctuations in area and weight component allocation throughout the growing season. At 28 days after planting, stipules comprised $34 \%, 76 \%$, and $53 \%$ of the total leaf area, and tendrils comprised $6 \%, 24 \%$, and $13 \%$ of the total leaf area in normal, afila, and afila-tendrilled acacia types, respectively. At harvest, stipules composed $43 \%, 60 \%$, and $53 \%$ of the total leaf area and tendrils composed $15 \%, 40 \%$, and $22 \%$ of the total leaf area in normal, afila, and afilatendrilled acacia types, respectively. Results from this study demonstrate that significant seasonal variation in allocations of foliage area and weight components exists among these three foliage types.
\end{abstract}

The afila (af) and tendrilled-acacia (tac) genes modify the normal pea leaf. Since the discovery of the af gene (Goldenberg, 1965; Kujala, 1953), which replaces leaflets with tendrils, foliage mutants have held promise for restructuring pea canopy architecture. Cultivars homozygous for $a f$, which are also known as semi-leafless, are being used throughout the world. In 1972 Sharma reported the tendrilled-acacia gene (tac). When present in the homozygous recessive condition, tac restores small leaflets to the tendrils of af plants. Both af and tac are considered homeotic mutants. Tissues from one segment of the leaf, i.e., tendrils for $a f$ and leaflets for tac, are transformed into tissues of another (Marx, 1987). Homeotic mutants in Pisum present novel phenotypes that may enhance pea improvement efforts. The afila-tac (afaf-tactac) and afila (afaf-TacTac) phenotypes have been described and studied agronomically (Goldman and Gritton, 1992; Goldman et al., 1992; Lafond et al., 1981; Wehner and Gritton, 1981), but little is known of how their foliage components are distributed in the pea leaf canopy during the growing season. Information of this type may help explain agronomic performance differences between the three foliage types and aid breeders in their quest to improve canopy architecture.

Although introduction of one or both of these genes into standard cultivars results in gross morphological changes of the pea leaf, nothing is known of the allocation of foliage area and weight components in these two mutant phenotypes relative to the normal foliage type. The objective of this study was to compare the allocation and distribution of stipule, tendril, leaf-

Received for publication 22 Apr. 1991. Accepted for publication 26 May 1992. Research supported by the College of Agricultural and Life Sciences, Hatch project 142-2804, and the Midwest Food Processors Assn. The cost of publishing this paper was defrayed in part by the payment of page charges, Under postal regulations, this paper therefore must be hereby marked advertisement solely to indicate this fact.

${ }^{1}$ Assistant Professor.

${ }^{2}$ Professor. let, and tac leaflet area and weight components in three fieldgrown pea foliage types throughout the growing season.

\section{Materials and Methods}

\section{Genetic material}

This study included normal (AfAf-TacTac), afila (afaf-TacTac), and afila-tendrilled acacia (afaf-tactac, referred to in this paper as afila-tac) near-isogenic lines in three genetic backgrounds: 'Alsweet 4683', 'Frontier', and 'Dark Skin Perfection'. 'Alsweet $4683^{\prime}$ is an early maturing canning pea cultivar, and 'Frontier' and 'Dark Skin Perfection' are mid- and late-maturing cultivars for canning and freezing, respectively. The tac gene used in these studies was obtained from B. Sharma (Division of Genetics, Indian Agricultural Research Inst., New Delhi, India) and incorporated via the backcross procedure. The sixth backcross was made in Fall 1986, and the $\mathrm{BC}_{6} \mathrm{~F}_{1}$ plants were grown in the greenhouse in the spring. All near-isolines were $\mathrm{BC}_{6} \mathrm{~F}_{6}$-derived at the beginning of the study.

\section{Design of experiment}

A split-plot treatment arrangement of a randomized complete block design with genetic background as whole plot and foliage type as subplot was employed. Four replications were planted in $1.1 \times 1.5-\mathrm{m}$ seven-row plots. Between-row spacing was 18 $\mathrm{cm}$, with seeds hand-spaced $2.5 \mathrm{~cm}$ apart in the row. The experiment was conducted in three environments: at the Arlington Agricultural Research Station, Arlington, Wis., in 1989 and 1990 on Plano silt loam soil (Typic Arguidolls) and the West Madison Agricultural Research Station, Madison, Wis., in 1989 on Plano silt loam soil (Typic Arguidolls).

\section{Cultural practices}

Planting dates at Arlington were 27 Apr. and 1 May 1989 and 1990, respectively, and 3 May 1989 at West Madison. 
Seeds were treated with the fungicide N-trichloromethylthio-4cyclohexene-1,2-dicarboximide (captan) before planting. $(\alpha-\alpha$ $\alpha$-trifluoro-2,6-dinitro-N,N-dipropyl-p-toluidine (trifluralin) was incorporated before planting at a rate of 0.17 liters.ha- 1 in all trials to control weeds. Supplemental weeding was by hand. Fertilizer was applied broadcast according to soil analyses and incorporated into the soil before planting. Because of a dry spring in 1989, $25 \mathrm{~mm}$ of irrigation was applied shortly after planting.

\section{Sampling practices}

Samples composed of 10 plants randomly chosen from three separate $600-\mathrm{cm}^{2}$ bordered sections of the plots were taken three times during the growing season: 28 days after planting, at the $100 \%$ bloom stage, and at green pea harvest $(\approx 100$ on tenderometer, the optimal harvest stage for commercial pea processing). The decision to sample 10 plants was based on sample size estimates reported by Gritton and Chi (1972). All three foliage types in a given genetic background were removed simultaneously at each sampling date. Each of the samples was placed in an airtight plastic bag and kept in a refrigerator until analysis, within $48 \mathrm{~h}$. Since sufficient material for tenderometer evaluation was not available for the final sampling date in this study, sampling decisions were based on tenderometer readings of similar cultivars in an adjacent trial.

The 10-plant sample was separated into the foliage components, i.e., stipule, leaflet, tendril plus petiole, and tac leaflet. Foliage component areas were measured with a LI-COR 3100 (LI-COR, Lincoln, Neb.) leaf area meter. The area of tendril plus petiole was corrected by $\pi / 2$ (Harvey and Goodwin, 1978) to account for their cylindrical shapes. Throughout the text, the tendril plus petiole component is designated as either tendril area or tendril weight. Total foliage area for each foliage type at each sampling date was calculated as the sum of tendril and stipule, plus the leaflet or tac leaflet component, where appropriate. The percentage of total leaf area due to these components was calculated by dividing the area of each component by the total leaf area and multiplying by 100 . All foliage components were dried for $48 \mathrm{~h}$ at $37 \mathrm{C}$ to determine dry weight. Total dry weight of foliage at each sampling date was calculated as the sum of stipule and tendril, plus leaflet and tac leaflet where appropriate. The percentage of foliage due to each of these components was calculated by dividing the weight of the component by the total dry weight and multiplying by 100. All foliage area and weight data are expressed on a per plant basis.

\section{Statistical analyses}

Data were tested by analysis of variance using the GLM procedure of SAS (Statistical Analysis Systems, Cary, N.C.). Each year-location combination was considered an environment, and a combined analysis of variance was performed across all environments. All effects in the analysis, with the exception of environments and replicates, were treated as fixed. Type III sums of squares were used to compute mean squares due to missing data. Comparisons among means were made by least significant difference.

\section{Results and Discussion}

The combined analysis of variance across genetic backgrounds and environments revealed highly significant genetic background $\times$ foliage type and environment $\times$ foliage type interactions. Also present were genetic background main effects for percentage of leaf area and weight due to stipule and tendril at each sampling date (Table 1). Despite the importance of genetic background effects in the performance of the afila-tac foliage type (Goldman and Gritton, 1992), the interaction of genetic background $x$ foliage type was due to changes in magnitude of means, rather than changes in rank; therefore, foliage type means were averaged over genetic backgrounds. Similarly, foliage type means were averaged over environments, since the environment $\times$ foliage type interaction was also due to changes in magnitude, rather than rank, of means.

At 28 days after planting, stipules made up three-fourths of afila and only one-third of normal leaves (Table 2); the afilatac type was intermediate. Similar trends were noted for percentage of total leaf weight due to stipules (Table 3). Highly significant differences among foliage types in the percentage of leaf area and weight due to tendrils were also measured at 28

Table 1. Significance levels of mean squares from the combined analysis of variance for pea foliage area and weight variables over three environments.

\begin{tabular}{ccclccc}
\hline \hline & \multicolumn{6}{c}{ Source of variation $^{z}$} \\
\cline { 2 - 7 } Component & $G$ & $G \times E$ & $\begin{array}{l}F \\
\text { Degrees of freedom }\end{array}$ & G $\times F \times E$ \\
\cline { 2 - 7 } & 2 & 6 & 2 & 6 & 4 & 12 \\
\hline
\end{tabular}

\begin{tabular}{|c|c|c|c|c|c|c|}
\hline Component & 2 & 6 & 2 & 6 & 4 & 12 \\
\hline \multicolumn{7}{|c|}{ Foliage area contribution at 28 days after planting } \\
\hline Stipule & $*$ & NS & ** & NS & NS & NS \\
\hline Tendril & $* *$ & $* *$ & $* *$ & NS & NS & NS \\
\hline Leaflet & $* *$ & NS & $*$ & $* *$ & NS & NS \\
\hline Tac leaflet & NS & NS & $* *$ & NS & NS & NS \\
\hline Total area & $*$ & NS & $* *$ & NS & NS & NS \\
\hline \multicolumn{7}{|c|}{ Foliage weight contribution at 28 days after planting } \\
\hline Stipule & $* *$ & $*$ & $* *$ & $*$ & $* *$ & NS \\
\hline Tendril & NS & NS & $* *$ & NS & $* *$ & NS \\
\hline Leaflet & $* *$ & NS & $* *$ & $* *$ & $* *$ & NS \\
\hline Tac leaflet & $* *$ & $* *$ & $* *$ & $* *$ & ** & $* *$ \\
\hline Total dry wt. & NS & NS & $* *$ & NS & NS & NS \\
\hline \multicolumn{7}{|c|}{ Foliage area contribution at $100 \%$ bloom } \\
\hline Stipule & $* *$ & NS & $* *$ & NS & $* *$ & NS \\
\hline Tendril & $* *$ & NS & $* *$ & $* *$ & $* *$ & NS \\
\hline Leaflet & $* *$ & $* *$ & ** & $* *$ & ** & $* *$ \\
\hline Tac leaflet & $* *$ & NS & $* *$ & $* *$ & $* *$ & * \\
\hline Total area & $* *$ & $* *$ & $* *$ & NS & NS & NS \\
\hline \multicolumn{7}{|c|}{ Foliage weight contribution at $100 \%$ bloom } \\
\hline Stipule & $* *$ & NS & $* *$ & NS & NS & NS \\
\hline Tendril & $* *$ & NS & $* *$ & $* *$ & $* *$ & NS \\
\hline Leaflet & NS & NS & $* *$ & NS & NS & NS \\
\hline Tac leaflet & $* *$ & NS & $* *$ & $* *$ & NS & NS \\
\hline Total dry wt. & ** & NS & $*$ & NS & NS & NS \\
\hline \multicolumn{7}{|c|}{ Foliage area contribution at green pea harvest } \\
\hline Stipule & $* *$ & NS & $* *$ & NS & $* *$ & NS \\
\hline Tendril & $* *$ & $*$ & $* *$ & $*$ & $* *$ & $*$ \\
\hline Leaflet & $* *$ & NS & $* *$ & NS & $* *$ & NS \\
\hline Tac leaflet & $* *$ & NS & $* *$ & $* *$ & $* *$ & NS \\
\hline Total area & $* *$ & NS & $*$ & $* *$ & NS & NS \\
\hline \multicolumn{7}{|c|}{ Foliage weight contribution at green pea harvest } \\
\hline Stipule & $* *$ & $* *$ & $* *$ & NS & NS & NS \\
\hline Tendril & $* *$ & NS & ** & NS & NS & NS \\
\hline Leaflet & NS & NS & $* *$ & NS & NS & NS \\
\hline Tac leaflet & $*$ & NS & $* *$ & NS & $*$ & NS \\
\hline Total dry wt. & $* *$ & NS & NS & NS & $*$ & $*$ \\
\hline
\end{tabular}

${ }^{\mathrm{z}}$ Sources of variation are: $\mathrm{G}=$ genetic background, $\mathrm{E}=$ environment, $\mathrm{F}=$ foliage type.

${ }^{*, * *, N S}$ Significance based on $\mathrm{F}$ test at $P<0.05$ and 0.01 or nonsignificance, respectively. 
Table 2. Seasonal variation in leaf area component allocation in three pea foliage types averaged over three genetic backgrounds and three environments.

\begin{tabular}{|c|c|c|c|c|c|}
\hline \multirow{2}{*}{$\begin{array}{l}\text { Sampling date } \\
\text { and } \\
\text { foliage type }\end{array}$} & \multicolumn{4}{|c|}{ Trait (\% of total leaf area) } & \multirow{2}{*}{$\begin{array}{r}\text { Total } \\
\text { area } \\
\left(\mathrm{cm}^{2}\right) \\
\end{array}$} \\
\hline & Stipule & Tendril & $\begin{array}{c}\text { Leaflet } \\
\text { area }\end{array}$ & $\begin{array}{l}\text { Tac } \\
\text { area } \\
\end{array}$ & \\
\hline \multicolumn{6}{|c|}{28 Days after planting } \\
\hline AfAf-TacTac & 34 & 6 & 60 & --- & 54 \\
\hline afaf-TacTac & 76 & 24 & --- & --- & 41 \\
\hline afaf-tactac & 53 & 13 & --- & 35 & 46 \\
\hline $\operatorname{LSD}_{0.05}{ }^{2}$ & 1 & 1 & -- & -- & 2 \\
\hline \multicolumn{6}{|l|}{$100 \%$ Bloom } \\
\hline AfAf-TacTac & 47 & 12 & 41 & -- & 295 \\
\hline afaf-TacTac & 68 & 32 & $\cdots$ & -- & 244 \\
\hline afaf-tactac & 63 & 24 & $\cdots$ & 13 & 287 \\
\hline $\operatorname{LSD}_{0.05}$ & 2 & 1 & $\cdots$ & --- & 20 \\
\hline \multicolumn{6}{|c|}{ Green pea harvest } \\
\hline AfAf-TacTac & 43 & 15 & 41 & --- & 226 \\
\hline afaf-TacTac & 60 & 40 & -- & --- & 198 \\
\hline afaf-tactac & 53 & 22 & $\cdots$ & 25 & 218 \\
\hline $\mathrm{LSD}_{0.05}$ & 2 & 2 & -.. & --. & 18 \\
\hline
\end{tabular}

${ }_{\mathrm{z}}^{\mathrm{z}}$ Foliage type means greater than this value are significantly different at $P=0.05$.

days after planting. Tendril contribution to total leaf area was $6 \%$ in normal and four times that amount in afila. An identical relationship was observed between these foliage types for tendril weight. These results could be expected based on the presence of $a f$. The tendril area contribution in afila-tac was again intermediate at $13 \%$, and the tendril weight contribution in afila-tac was intermediate at $15 \%$. Both tendril area and weight contributions in afila-tac were roughly twice as high as for normal. At 28 days after planting, tac leaflets made up about one-third of the total leaf area and total leaf weight. The normal type had a significantly larger total leaf area and higher total dry weight than either afila or afila-tac at this time.

At the $100 \%$ bloom stage, significant differences in stipule contribution to total leaf area and total leaf weight were detected between normal and afila. At this stage, however, the difference between the two foliage types was not as great as that measured at 28 days after planting. Interestingly, the percentage of total leaf area due to stipules was similar in afila and afila-tac. The percentage of the total leaf area due to stipules was $68 \%$ in afila, while the stipule weight contribution was only $52 \%$. This result suggests that the ratio of mass to unit area of the pea leaf was smaller at the second than at the first sampling date. Significant differences in tendril area contribution to total leaf area existed among the three foliage types. The afila-tac type had twice as much tendril area contribution to total leaf area as normal. A similar relationship was measured at 28 days after planting. Tendril contribution to total foliage area in afila (32\%) was highest of the three foliage types. This was more than 2.5 times as large as the tendril contribution in normal. The percentage of leaf weight due to weight of tendrils was highest in afila. The percentage of total leaf weight due to tendrils in all three foliage types was higher than the percentage of total leaf area due to tendrils. The tendril foliage component, unlike stipules, exhibited larger increases in weight (as a percentage of total leaf weight) than area (as a percentage of total leaf area) as the season progressed. In this case, the ratio of mass per unit area increased from sampling date 1 to sampling date 2. Substantial decreases (compared to 28 days after planting) were observed for the percentage of leaf area and weight due to leaf-
Table 3. Seasonal variation in leaf weight component allocation in three pea foliage types averaged over three genetic backgrounds and three environments.

\begin{tabular}{|c|c|c|c|c|c|}
\hline \multirow{2}{*}{$\begin{array}{l}\text { Sampling date } \\
\text { and } \\
\text { foliage type }\end{array}$} & \multicolumn{4}{|c|}{ Trait ( $\%$ of total leaf weight) } & \multirow{2}{*}{$\begin{array}{c}\text { Total wt } \\
(\mathrm{g})\end{array}$} \\
\hline & Stipule & Tendril & Leaflet & Tac & \\
\hline \multicolumn{6}{|c|}{28 Days after planting } \\
\hline AfAf-TacTac & 30 & 8 & 62 & --. & 0.19 \\
\hline afaf-TacTac & 68 & 32 & -- & $-\cdots$ & 0.14 \\
\hline afaf-tactac & 49 & 15 & --- & 36 & 0.17 \\
\hline $\mathrm{LSD}_{0.05} \mathrm{z}^{\mathrm{z}}$ & 3 & 3 & -- & -- & 0.01 \\
\hline \multicolumn{6}{|l|}{$100 \%$ Bloom } \\
\hline AfAf-TacTac & 40 & 22 & 37 & -- & 0.65 \\
\hline afaf-TacTac & 52 & 47 & --- & -- & 1.19 \\
\hline afaf-tactac & 50 & 37 & $-\ldots$ & 12 & 1.02 \\
\hline $\mathrm{LSD}_{0.05}$ & 3 & 2 & --- & --- & 0.12 \\
\hline \multicolumn{6}{|c|}{ Green pea harvest } \\
\hline AfAf-TacTac & 35 & 28 & 37 & --- & 1.78 \\
\hline afaf-TacTac & 44 & 55 & --- & --- & 1.68 \\
\hline afaf-tactac & 44 & 34 & --- & 22 & 1.79 \\
\hline $\mathrm{LSD}_{\mathrm{nO5}}$ & 1 & 1 & -- & --- & NS \\
\hline
\end{tabular}

${ }^{\mathrm{z}}$ Foliage type means greater than this value are significantly different at $P=0.05$

lets and tac leaflets at the $100 \%$ bloom stage. These decreases were offset primarily by the previously mentioned increases in stipule and tendril contributions to total leaf area and weight. No significant difference in total leaf area was detected between normal and afila-tac at the $100 \%$ bloom stage or at the green pea harvest stage. These two foliage types had significantly larger total leaf area than afila at these two stages.

An interesting relationship between total leaf area and total leaf weight was observed for normal and afila plants. Total leaf area was significantly higher in normal plants as compared to afila plants at $100 \%$ bloom, but total leaf weight of normal plants was less than that of afila. Therefore, the ratio of mass per unit area of normal plants was significantly less than that of afila or afila-tac plants at $100 \%$ bloom. These data also suggest that net assimilation rates of these three foliage types may not be constant throughout the growing season. Data collected on above-ground biomass reveal that the normal foliage type had the largest biomass of the three types at harvest, but the lowest of the three at $100 \%$ bloom. Thus, the net assimilation rate of the normal foliage type apparently may have been significantly lower than that of the afila or afila-tac type until $100 \%$ bloom and significantly higher by green pea harvest. This change in assimilation rate seems not to be related to foliage component allocation, since the relative percentages of stipule, tendril, and leaflet change little in the normal foliage type from $100 \%$ bloom to green pea harvest.

The afila type had higher stipule area and tendril area contributions to total leaf area than the other foliage types at green pea harvest. There are conflicting reports in the literature about the difference in stipule area contribution to leaves of the afila and normal types. Wehner and Gritton (1981) found no significant difference between the stipule area of afila and normal leaves, whereas Harvey (1976) and Gonzalez-Lauck (1990) demonstrated that afila leaves have a larger stipule area than normal leaves. Our data (absolute amounts rather than percentages) support the finding that afila types have a larger stipule area than normal types throughout the growing season. As mentioned previously, when data are examined by percentage of the total leaf area due to stipule area, afila far exceeds normal at each sampling date. The trends in percentages of total leaf weight 
due to stipules and tendrils were similar to those measured for total leaf area due to these components.

Tendril area contribution to total foliage area in afila was $\approx 2.5$ times as high as in normal at green pea harvest. Wehner and Gritton (1981) found that the tendril plus petiole component of afila leaves was 2.1 times larger than for normal leaves at the green pea harvest stage. Leaflet area contribution remained at $41 \%$ in normal. As was measured for leaflet area, the percentage of total leaf weight due to leaflets in normal remained constant at the second and third sampling dates. The contribution of tac leaflets to area increased to $25 \%$ at the green pea harvest stage compared to $13 \%$ at the $100 \%$ bloom stage. A seasonal increase in the area contribution of tac leaflets has also been noted in afila-tac lines (Goldman et al., 1992). A similar increase was noted in the percentage of leaf weight due to tac leaflets.

Yield relationships among these three foliage types have been reported (Goldman et al., 1992). In general, afila-tac exhibited significantly lower yield on both a per-plant basis and a perarea basis than either normal or afila. Yield differences between normal and afila were generally not significant. Although allocation of leaf components may play a significant role in the yielding ability of these foliage types, other factors, such as reductions in fertility with the addition of the tac gene, may be responsible for yield differences (Goldman et al. 1992). At green pea harvest, the afila-tac leaf exhibited values intermediate between normal and afila for percent stipule and tendril area and for total foliage area, yet significant yield reductions were observed when compared to these two foliage types. General trends of the relationship between foliage area allocation and yield response of these foliage types were not detected in the current study.

Stipule contribution to total foliage area and weight in afila continued to decrease throughout the growing season, while tendril contribution in afila continued to increase. Stipule contribution to total foliage area and weight in normal and afila-tac reached a peak at $100 \%$ bloom. Tendril contribution to total foliage area and total foliage weight in afila-tac reached a peak at $100 \%$ bloom, while in normal it rose gradually throughout the season. At the green pea harvest stage, normal had about equal stipule and leaflet percentage contributions to total foliage area, and afila-tac had about equal tendril and tac leaflet area contributions. At green pea harvest, however, the percentage of total leaf weight due to stipules and leaflets were about equal in normal, but the tendril weight contribution to total leaf weight in afila-tac was higher than the tac leaflet weight contribution.

This experiment demonstrated that the allocation of foliage component areas and weights in these pea foliage types varied both within a sampling date and across the growing season. At a given sampling date, the percentage of total leaf area or weight due to stipules or tendrils may vary by $>200 \%$ among these three foliage types. Significant fluctuations in foliage area and weight relationships between these foliage types suggest that differences in net assimilation rates may exist throughout the growing season.

Although alterations in foliage morphology resulting from addition of the af and tac genes may present the breeder with novel phenotypes, there is no evidence from this study to suggest that improvement of either of these two mutant foliage types will result in superior plant productivity. On the contrary, Goldman et al. (1992) found that the afila-tac foliage type exhibited significantly lower yield than either afila or normal foliage types on both a per-plant and per-area basis. However, no significant differences were detected between the afila and normal foliage types in that study, suggesting that further study and modification of the afila foliage type may be considered in pea breeding programs.

\section{Literature Cited}

Goldenberg, J. 1965. "Afila," a new mutation in pea (Pisum sativum L.). Bol. Genet. 1:27-28.

Goldman, I.L. and E.T. Gritton. 1992. Agronomic evaluation and expression of the tendrilled-acacia (tac) trait in semi-leafless peas. I. Field performance under minimal competition. Crop Sci. 32:851855.

Goldman, I.L., E.T. Gritton, and P.J. Flannery. 1992. Agronomic evaluation and expression of the tendrilled-acacia (tac) trait in semileafless peas. II. Field performance under high competition. Crop Sci. 32:855-861.

Gonzalez-Lauck, V.W. 1990. Agronomic evaluation, plant morphology, growth analysis and physiological characteristics of normal leaf and semi-leafless (afila) varieties of processing peas. Diss. Abstr. 9027497, Univ. of Wisconsin, Madison.

Gritton, E.T. and Pi-Yeong Chi. 1972. Sampling procedures and optimum sample size for estimating yield components in peas (Pisum sativum L.) J. Amer. Soc. Hort. Sci. 97:451-453.

Harvey, D.M. 1976. The photosynthetic and respiratory potential of the fruit of leafless and semi-leafless mutants of Pisum sativum. Annu. Rpt., John Innes Inst. p. 27-30.

Harvey, D.M. and J. Goodwin. 1978. The photosynthetic net carbon dioxide exchange potential in conventional and 'leafless' phenotypes of Pisum sativum L. in relation to foliage area, dry matter production and seed yield. Ann. Bot. 42:1091-1098.

Kujala, V. 1953. Felderbse, bei welcher die ganz Blattspreite in Ranken umgewandelt ist. Arch. Soc. Zool. Bot. Fenn. "Vanamo" 8:4445.

Lafond, G., S.T. Ali-Kahn, and L.E. Evans. 1981. Comparison of near-isogenic leafed, leafless, semi-leafless, and reduced stipule lines of peas for yield and associated traits. Can. J. Plant Sci. 61:463465.

Marx, G.A. 1987. A suite of mutants that modify pattern formation in pea leaves. Plant Molec. Biol. Rpt. 5:311-335.

Sharma, B. 1972. "Tendrilled acacia," a new mutation controlling tendril formation in Pisum sativum. Pisum Nwsl. 4:50.

Wehner, T.C. and E.T. Gritton. 1981. Horticultural evaluation of eight foliage types of peas near-isogenic for the genes af, $t l$, and st. $\mathrm{J}$. Amer. Soc. Hort. Sci. 106:272-278. 